Editorial

\title{
Subclinical hypothyroidism: the importance of information to the patient as part of the management
}

\section{Editorial}

The term subclinical hypothyroidism ( $\mathrm{SCH}$ ) began to be used in the early seventies, ${ }^{1} \mathrm{SCH}$ is defined based on biochemical criteria by mildly elevated serum levels of TSH with Total o Free T4 values within the normal range, without considering clinical features (Symptoms and Signs). SCH is highly prevalent in the adult population worldwide..$^{2-4}$ The clinical transcendence of SCH lies not only in its high prevalence in the population, but also in its possible association with ischemic heart disease, peripheral arterial disease, depression and anomalies of lipid profile. ${ }^{5}$

The treatment of $\mathrm{SCH}$ is a matter of debate, since $\mathrm{SCH}$ is usually of poor clinical expression and treatment with levothyroxine is not accompanied by evident clinical improvement. ${ }^{6}$ In the current clinical practice Levothyroxine therapy are recommended for patients with TSH persistently $>10 \mathrm{mIU} / \mathrm{L}$, but controversy persist in cases of patients with concentrations $\leq 10 \mathrm{mIU} / \mathrm{L} .{ }^{7,8}$

Another kind of problems should also be considered in this topic, such as the disinformation of patients and the concern that this entails. From my clinical practice and from the reading of patients' forums on the international networks I perceive the discontent of the patients with the way in which the doctors handle the patients with $\mathrm{SCH}$ which I illustrate below:

It is not uncommon for doctors to tell their patients that because they have subclinical hypothyroidism, the symptoms they suffer cannot be attributed to thyroid dysfunction, a statement that is false, because the definition of SCH does not imply clinical manifestation, in addition around $30 \%$ of SCH patients may have symptoms suggestive of thyroid hormone deficiency. ${ }^{2,9}$

Another source of confusion and concern occurs when the doctor tells the patient that he has an $\mathrm{SCH}$ but she or he must wait for the disease progress or get worse to treat her or him, when it is generally known that a disease must be treated as early as possible.

The aforementioned comes with something that we doctors know and must keep in mind, that inadequate information to the patient can add suffering to the disease itself.

In conclusion, accurate and sufficient information is necessary as an important part of disease management, and more so in the case of diseases as $\mathrm{SCH}$ in which there is debate about its definition or clinical significance.

\section{Acknowledgments}

None.

\section{Conflicts of interest}

The author declares that there are no conflicts of interest.
Volume 5 Issue 5 - 2017

\author{
RicardoV García-Mayor \\ South Galicia Institute of Health, University Hospital of Vigo, \\ Spain
}

Correspondence: Ricardo V García-Mayor, South Galicia Institute of Health, University Hospital of Vigo, Technic Block, 2nd floor, 34I Clara Campoamor Street, 363 I2 Vigo, Spain, Tel +34/630/963 866, Email ricardo.garcia.mayor@sergas.es

Received: October 28, 2017 | Published: November 3, 2017

\section{Funding}

None.

\section{References}

1. Evered D, Hall R. Hypothyroidism. Br Med J. 1972;1(5795):290-293.

2. Canaris GJ, Manowitz NR, Mayor G, et al. The Colorado thyroid disease prevalence study. Arch Intern Med. 2000;160(4):526-534.

3. Parle JV, Franklin JA, Garry Pj, et al. Prevalence and follow-up of abnormal thyrotropin (TSH) concentrations in elderly in the United Kingdom. Clin Endocrinol (Oxf.). 1991;34(1):77-83.

4. Rivolta G, Cerrutti R, Colombo R, et al. Prevalence of subclinical hypothyroidism in a population living in the Milan Metropolitan area. $J$ Endorinol Invest. 1999;22(9):693-697.

5. Rego Iraeta A, Regal M, Catalina P, et al. Subclinical hypothyroidism: concept, etiology, repercussions and treatment. Endocinology. 1996;43:152-155.

6. Burns RB, Bates CK, Hartzband P, et al. Should we treat for subclinical hypothyroidism? Ann Inter Med. 2016;164(11):764-770.

7. Garber JR, Cobin RH, Gharib H, et al. Clinical practice guidelines for hypothyroidism in adults: cosponsored by the American Association of Clinical Endocrinologist and the American Thyroid Association. Endocr Pract. 2012;18(6):988-1028.

8. Pearce SHS, Brabant G, Duntas LH, et al. ETA Guideline: management of subclinical hypothyroidism. Eur Thyroid J. 2012;2(4):215-228.

9. Zulewski H, Muller B, Exer P, et al. Estimation of tissue hypothyroidism by a new clinical score: evaluation of patients with various grades of hypothyroidism and controls. J Clin Endocrinol Metab. 1997;82(3):771-776. 